\title{
Heterotopik Bir Mekân: Tophane-i Amire Kültür ve Sanat Merkezi
}

\author{
Ayşe Gülçin URAL ${ }^{1 *}$
}

\section{Öz}

Mimari yapılar, senelerce ayakta kalmış, farklı dönemlere şahitlik etmiş olup, yapının formu ve konumu doğrultusunda farklı kullanımlar için yeniden işlevlendirilebilirler. Bu yapılar, önceki işlevinin yeni mekân organizasyonunu olumsuz etkilememesi gözetilerek tasarlanırken, önceki işlevine dair göstergeleri ve o döneme ait hissiyatı kullanıcılarına aktarır. Bazı yapılar ise yeni ve eski işlevini aynı anda kullanıcıya hissettirebilir. Böylece mekân kullanıcıda parçalı olarak algılanırken bütünlüğün tamamen ortadan kalkmadığı, heterojen olduğu görülür. Kullanıcısına 'öteki mekân' deneyimi yaşatarak, Foucault'un ifadesiyle ‘ayna' görevi görürler.

20.yy filozoflarından Michel Foucault'un mekân hakkında yaptığı çalışmalar genelde kurum binaları üzerinde yoğunlaşmıştır. Bunun yanında kavramsal mekânla ilgili 'heterotopya kavramı'nı geliştirmiştir. Heterotopik mekânların kullanıcı üzerindeki etkisinin yanında kentsel tasarımların ve yapıların heterotopya kavramıyla olan denkliği de araştırmalara konu olmuştur.

Bu çalışmada önemli bir tarihe sahip, çeşitli medeniyetlere ev sahipliği yapmış ve pek çok tarihi yapıyı bulunduran İstanbul şehrinde, heterotopya kavramına karşılık gelebilecek yapılar olduğu düşünülmüştür. Bu doğrultuda Tophane semtinde yer alan Tophane-i Amire Kültür ve Sanat Merkezi heterotopik mekân olarak incelenmiştir.

Çalışma hazırlanırken nitel araştırma yöntemlerinden genel tarama modeli kullanılarak tespit yapılmak istenmiştir. Michel Foucault'un mekân ve heterotopya hakkındaki metinleri taranmıştır. Ardından Tophane-i Amire'nin tarihine dair yazılı metinler incelenmiştir. Araştırma nesnesi olarak seçilen mekânın 'heterotopik' değerlendirimesi ve kavramın somut bir örnekle incelenmesi amaçlanmıştır.

Anahtar Kelimeler: Heterotopya, Tophane-i Amire, Michel Foucoult, Heterojen Mekân

\section{A Heterotopic Place: Tophane-i Amire Culture and Art Center}

\section{Abstract}

Architectural structures have survived for years, witnessed different periods and can be refunctionalized for different uses according to the form and location of the building. These structures are designed by taking into consideration that the previous function does not adversely affect the new space organization, and it transmits the indicators of the previous function and the feeling of that period to its users. Some structures can make the user feel

\footnotetext{
${ }^{1}$ Mimar Sinan Güzel Sanatlar Üniversitesi, Fen Bilimleri Enstitüsü, İç Mimarlık Doktora Programı, İstanbul, Türkiye *ilgili Yazar / Corresponding Author: gulcinn.ural@gmail.com Gönderim Tarihi: 04.03.2019

Kabul Tarihi: 29.06.2019
} 
new and old at the same time. In this way, the user detects the space in a fragmented manner, but the integrity is not eliminated and is heterogeneous. It serve as 'mirror' with Foucault's expression, giving the user experience of 'other space'.

Michel Foucault, one of the 20th century philosophers, focuses on the premises of the institution. Besides, he developed the concept of heterotopia about conceptual space. Similar to the effect of heterotopic spaces on the user, the equivalence of urban designs and structures with the concept of heterotopia has been the subject of research.

In this study, the city of Istanbul, which has an important history, hosted several civilizations and had many historical buildings, was thought to be the structures that conform to the concept of heterotopia. The Tophane-i Amire Culture and Art Center in the Tophane district has been investigated as a heterotopic space.

While preparing the study, it was aimed to determine the qualitative research methods by using the general screening model. Michel Foucault's texts on space and heterotopia were scanned. Then, written texts about the history of Tophane-i Amire were examined. The aim of this study is to evaluate heterotopically the selected space as research object and to examine the concept with a concrete example.

Keywords: Heterotopia, Tophane-i Amire, Michel Foucoult, Heterogeneous space

\section{GíRiş}

Michel Foucault, 'Öteki Mekân' isimli makalesinde "İçinde yaşadığımız, bizi kendi dışımıza çıkaran, hayatımızın, zamanımızın ve tarihimizin erozyonuna sahne olan, bizi yiyip bitiren mekân, aynı zamanda bizatihi heterojen bir mekândır." diyerek mekânın heterojen bir yapısı olduğunu dile getirmiştir (Foucault, 1984, s. 9). Beşeri ögelerin depolandığı ve ilişki ağlarının kurulduğu mekânı Bachelard'ın yorumunu benimseyerek değerlendirmiştir. Buradan yola çıkarak 'heterotopya' kavramını geliştirmiş ve altı temel ilkeye dayandırmıştır. Foucault'un mekâna dair bu yaklaşımı daha sonrasında yapılan pek çok araştırmaya konu olmuştur. Bu araştırmalar yazılı olmakla kalmamış, mevcut mekânların heterotopya kavramı üzerinden incelenmesi ile de yapılmıştır. Küçük ya da büyük ölçekli kamusal alanlar üzerinden değerlendirilebilecek olan kavram, araştırma nesnesi olarak seçilen mekâna dair farkındalığımızı artırma önemi taşımaktadır. Ele alınan örnek aracılığıyla kavramı daha net yorumlayabilme olanağımız oluşmaktadır.

Üç eksenli olarak yürütülen bu çalışmanın birinci aşamasında; heterotopya kavramı incelenmiştir. İlk olarak katmanlı mekânlardan söz edilerek Foucault'un heterojen mekânlara dair düşünceleri üzerinde durulmuştur. Ütopik ve heterotopik mekân arasındaki ayrım tespit edilmiştir. Buradan yola çıkarak heterotopik mekânların ilkelerine ve tespit yöntemlerine değinilmiştir. Foucault'un tabiri ile 'öteki mekân'ın kullanıcısına yansıması ile ortaya çıkan 'öteki ben' açıklanmaya çalışılmıştır. Kullanıcılarından ayrı değerlendirilemeyecek olan heterotopik mekânların, kişiler üzerinde yarattığı etki araştırılmıştır.

Çalışmanın ikinci aşamasında; araştırma nesnesi olarak seçilen, İstanbul'un Tophane semtinde bulunan Tophane-i Amire Kültür ve Sanat merkezi heterotopya kavramı 
üzerinden incelenmiştir. Seçilen mekânın heterotopya kavramına karşılık gelebileceği hipotezi ile bir tespit yapılmak istenmiştir. Tophane-i Amire Kültür ve Sanat Merkezi'nin tercih edilmesinin nedeni; çeşitli dönemlere şahitlik eden tarihi bir yapı olması ve 16. yy.'ın en büyük top döküm merkezi olarak önemli bir niteliğe sahip olmasıdır. İkinci önemli sebep ise; daha önceki işlevi ile şimdiki işlevinin üst üste çakıştırılamayacak anlamlar taşımasıdır. Eski fiziki yapısını büyük ölçüde korumasına rağmen fonksiyonel anlamda vurucu bir değişikliğe gidilmiş, kültür ve sanat merkezi olarak işlevlendirilmiştir. Bu nedenle, heterotopik olarak değerlendirilebileceği düşünülmüş, örneklem olarak tercih edilmiştir.

Üçüncü bölümde ise; Tophane-i Amire Kültür ve Sanat Merkezi binası heterotopya kavramı üzerinden değerlendirilmiştir. Kavramın detaylandırıldığı altı ilke üzerinden incelenerek, özelliklerini taşıdığı düşünülen ilkelerle bağlantısı aktarılmıştır.

$\mathrm{Bu}$ araştırmada; Foucault'un geliştirmiş olduğu 'heterotopya' kavramı incelenerek, İstanbul'da bulunan belirli bir yapı üzerinden değerlendirildiği için betimsel tarama modeli kullanılmıştır. Araştırma verileri ise nitel araştırma yöntemlerinden, literatür taraması modeli ile elde edilmiştir.

Literatür çalışmasında ilk olarak Michel Foucault'un "Öteki Mekân” makalesi incelenmiştir. Sonrasında, Foucault'un mekân hakkındaki fikirlerini belirttiği diğer çalışmaları taranmıştır. 1982 tarihli "Mekân, Bilgi, İktidar" söyleşisi incelenmiştir. Mekânı değerlendirirken Gaston Bachelard'ın düşüncelerini benimsediğini ifade etmiş olduğu için Bachelard'ın çalışmaları incelenmiştir. Foucault'un mimarlık ve mekân düzenlemesi hakkında görüşlerini içeren makalelerden yararlanılmıştır. Mekânın sosyolojisine dair fikir edinmek için Hasan Ünal Nalbantoğlu'nun kitabından faydalanılmıştır. Konu ile ilgili çalışmış başka araştırmacıların bakış açılarını görebilmek amacıyla, çeşitli mekânları heterotopya kavramı üzerinden değerlendiren tez çalışmaları ve makalelerin taraması yapılmıştır. Bunun yanında araştırma nesnesi olarak seçilen Tophane-i Amire Kültür ve Sanat Merkezi'nin tarihini araştırmak ve geçirmiş olduğu değişimleri tespit etmek amacı ile Mimar Sinan Güzel Sanatlar Üniversitesi'nin kütüphanesinden yararlanılmıştır. Tophane semti ve örneklem olarak seçilen yapı hakkında yazıımış kitap ve tez çalışmalarından faydalanılmıştır.

Araştırmanın sonuç bölümünde; Tophane-i Amire Kültür ve Sanat Merkezi'nin 'heterotopya' kavramı ile örtüştüğüne dair tespit yapılmak istenmiştir. Bu tespit ile kavrama dair değerlendirmelere, bir örneklemden faydalanarak ışık tutmak amaçlanmıştır. Bunun yanında, çeşitli medeniyetlere ev sahipliği yapmış olan İstanbul şehrinde, derin tarihinden ötürü, seçilen örnek gibi birçok yapı olduğu düşünülmektedir. Araştırma sonrası varılmış olan sonuç ile heterotopya kavramı incelenerek, bu kavram üzerinden sosyolojik mekân değerlendirmesi yapabilmek amaçlanmıştır. Bunun yanında, İstanbul'un merkezi noktalarından birinde bulunan bu kıymetli yapıya dair bir farkındalık yaratmak istenmiştir. Yapılmak istenen tespit ile başka yapıların da heterotopya kavramı ile örtüştüğüne dair ileride yapılabilecek çalışmalara faydalı olmak amaçlanmıştır.

\section{HETEROTOPYA VE MEKÂN}

Toplumsal teorisyen, eleştirmen, tarihçi ve felsefeci olan Michel Foucault'nun çalışmalarının konusu ‘özne'dir. Ağırlıklı olarak biyopolitika üzerinde çalışmalar yürütmüştür. Mekân üzerine yapmış olduğu çalışmalar genellikle kurum binaları üzerinden şekillenmiş, yönetimsellik ve beden politikalarına dair pek çok inceleme yapmıştır. Bunun 
yanında 1967 tarihinde kaleme aldığı ve 1984 tarihinde yayınlanan "Öteki Mekân (Başka Mekânlara Dair)" isimli makalesinde mekân konusu ile ilgili görüşlerini belirtmiştir. Heterotopya kavramına da ilk olarak bu makalesinde değinmiştir. Foucault kavramı ele alırken mekânı şöyle tanımlamıştır: "Daha da somut bir biçimde, mahal veya yer belirleme meselesi demografik açıdan da çıkmaktadır insanlığın karşısına. Bu insan mahalli ve yaşama mekânı meselesi yalnızca dünyada insanlar için yeterince yer olup olmadığı sorusundan ibaret değildir; muayyen bir durumda muayyen bir hedefe ulaşmak için ne tür yakınlık ilişkilerine başvurmak gerektiği, beşeri ögelerin depolanması, deveranı, işaretlenmesi ve tasnifinde nasıl bir yolun izleneceği sorusunu da ihtiva eder. Çağımızda mekân bize mahaller arasında ilişkiler gibi görünmektedir" (Foucault, 1984, s. 8).

Foucault, 19. yy'ın saplantısının tarih, 20. yy'ın saplantısının ise mekân olduğunu dile getirirken, çağdaş mekânın belli kutsiyelerden hala arınmamış olduğunu ifade etmiştir. Ortaçağda yapılmış şehir planlamaları ve yapılar kesin hiyerarşik sınırlar ile oluşturulmuştur. Bu nedenle mekânlarda kutsiyelerin etkisi doğrudan görülebilirken, çağdaş mekânda bu etkiler silikleştirilmiştir. Demografik bir çerçeve çizilmesine rağmen mekânlar üzerinde hâlâ etkisi bulunan hiyerarşik ilişkiler zinciri mahallerin iç içe geçmesine sebep olmuştur. Mahaller arasındaki ilişkiler olarak tanımlanan mekân, Foucault'a göre özneden ayrı düşünülemez. Burada Bachelard'a atıfta bulunarak, "Yeknesak ve boş bir mekânda değil, tam aksine, baştan sona kemiyetlerle dolu ve belki de tamamen hayali bir mekânda yaşamakta olduğumuzu öğretti bize." diyerek konuyu özne-mekân ilişkisi üzerinden ele aldığını belirtmiştir (Foucault, 1984, s. 9). "Öteki yer, akıldadır, deneyimdedir; bu sebeple, beden ile ilişkili olarak muğlak ve kararsız bir bağlama sahiptir. Öteki yer, tek bir beden için dahi bir tür çokluktur ve çokluğu oluşturan haller değişken ve geçicidir. Bedenlerin o mekânı deneyimleme hallerine bağlı olarak farklı anlamlarla yaratılan öteki yer, bir problematiktir, tartışmalı ve kesinleşmemiştir." (Kaymaz, 2017, s. 495). Benzer şekilde Bachelard mekânın zaman ile ilişkisini kurarak 'Mekânın Poetikası' adlı kitabında; "Mekân, peteklerinin binlerce gözünde, zamanı sıkıştırılmış olarak tutar. Mekân buna yarar." demiştir (Bachelard, 2014, s. 39).

Modernizmle beraber, içerdiği boşluğun tanımı ile değil de daha çok kavramsal yapısıyla algılanıp tanımlanmaya başlayan mekân için, insanlık tarihinin modern öncesi dönemlerinde bu soyutlamaya gerek duyulmamıştır (Nalbantoğlu, 2008, s. 88). Modernizm ile birlikte düzenlenen bu mekân tipleri içinde Foucault tarafından 'tuhaf' olarak tanımlanabilecek iki mekan tipi vardır: "Tüm diğer mekânlarla bağlantılı olan, fakat hepsiyle zıtlaşan bu mekânlar iki ana tipe ayrılabilir. Birincisi ütopyalar... Ütopyalar, gerçek bir yeri olmayan mahallerdir" (Foucault, 1984, s. 9). Ütopyalar toplumu ve dolayısıyla mekânı mükemmelleştirerek ya da tamamen ters yüz ederek sunarlar. Ancak herhalükarda gerçekdışıdırlar. Diğer mekânlar ise heterotopyalardır. Kelimenin kökenine bakıldığında heterotopik kelimesinin, Yunanca hetero ve topos kelimelerinin birleşmesinden oluştuğu görülmektedir. Hetero, Türk Dil Kurumu'na göre Yunanca'da 'diğer, farklı, başka' anlamlarına gelen bir ön ek olarak, Latince'de ise farklılığı veya benzemezliği ifade eden bir ön ek olarak kullanılmaktadır. Topos ise 'yer' anlamına gelmektedir (Dede, 2010 s. 12). Esasen bir anatomi terimi olan 'heterotopia', bir organın ya da dokunun bulunması gereken yerde bulunmaması ya da farklı bir yerde bulunması anlamına gelmektedir (Nakıboğlu, 2015, s. 384). Foucault ise mekân üzerinden heterotopyayı, gerçeklik içinde konumlanan ancak karşıt bir mahal olma vasfı taşıyan mekânlar olarak tariflemekte ve mekân-özne arasındaki ilişkiyi yapılandırmaktadır. Heterotopyayı "Bu yerler yansıttıkları ve dile getirdikleri tüm mahallerden kesinkes farklı olduğundan, ütopyaya tezat olarak heterotopya 
diye adlandıracağım ben bunları." şeklinde tanımlamaktadır (Foucault, 1984, s. 10). Heterotopik mekânlar ile 'ayna' arasında benzerlik kurmakta ve 'ayna'yı da heterotopya olarak değerlendirmektedir.

Aynada bulunan yansıma sebebiyle şu anda işgal etmekte olunan konuma alternatif olarak başka bir mekân ve 'ben' ile karşı karşıya kalınır. Gerçek ve gerçekdışı arasında sorgulamaya sebep olan bu durum karşıt mahalin yaratımına ya da ortaya çıkmasına sebep olan heterotopya ile varolur. Bu nedenle ayna bir heterotopyadır ve heterotopik mekânların yaratması beklenen etki budur.

Toplumsal değişimler ile yeniden tanımlanan heterotopik mekân, diğer mekânlarla olan ilişkisi ve mahalleri arasında olan ilişki ile gerçekliğini korurken, ayna görevi görerek planlamanın dışında bir etki yaratır. "Heterotopya toplumun nerede toplanacağını belirleyen ve toplumu kendi mekanlarının dışına doğru sürükleyen mekanlardır" (Girgin, Ertürk, Aysel, Akça, 2013, s. 396). Bu şekilde özne, ön görülenin dışında bir tecrübe yaşar. Focault, heterotopya kavramı ile mekânların dolaylı olarak sebep olduğu 'öteki ben'i aramaktadır. 'Öteki'yi ortayan çıkaran ise mahaller arasındaki ilişkidir. Öteki mekânların incelemesini hedef alacak sistematik bir tasvir tahayyül edilebileceğini söyler: "İçinde yaşadığımız mekâna, hem miti hem de gerçek bir ibraz olarak bu tasvire heterotopoloji diyebiliriz" (Foucault, 1984, s. 10). Heterotopolojiyi ise altı ilke ile belirlemiştir.

Bunların ilki; evrensel bir heterotopya tarzı bulunmamakla birlikte dünyada heterotopya kuramamış hiç bir kültürün olmadığıdır. İlk ilkeyi iki kategoride açıklar: Kriz heterotopyaları ve sapma heterotopyaları.

İkinci ilke; bir toplumun mevcut bir heterotopyayı, tarihi boyunca bambaşka biçimlerde işletebileceğidir. Kesin bir işleve sahip olan mekân, toplumun senkronisi uyarınca başka bir işleve sahip olabilir. Mekânların ve hatta daha geniş anlamda bölgelerin siyasal ve tarihsel özelliklerinin belirlenmesinde ekonomik, stratejik, yasal ve teknik değişkenlerin belirleyici olduğu anlaşılmaktadır. Bu ilke ile bağlantı kurulabilecek makalesinde Elden, "Foucault'nun meseleyi çetrefil bir hale getirerek; mevcut uygulamanın çoğunlukla o mekândaki bedenler üzerine olduğunu ileri sürdüğünü ve bölgenin değişkenlerinin, bölgede yaşayanlara yönelik bir uygulama olduğunu" aktarmaktadır (Elden, 2012, s. 482).

Üçüncü ilke; gerçek bir mekânda konumlanan ancak üstsüte bindirilmesi imkansız birkaç mekânın bir araya getirilmesidir. Sinema ya da tiyatro mekânları bunun örneğidir. İzleyicisi gerçekliğin içinde konumlanırken, izledikleri ile farklı mekânlara ve o an olduklarından farklı 'ben'lere ulaşabilir. Sahne ya da ekran aracılığıyla ayna etkisi yaşatııır.

Dördüncü ilke; Heterotopyalar çoğunlukla zaman dilimleriyle de bağlantıldır. İçinde bulunduğumuz zaman ile başka bir zamana gitme yolculuğu yaşanabilir. Bu ilke için iki zıt örnek verilebilir. İlk olarak müzeler ve kütüphaneler; zamanı, çağları, biçimleri biriktirme özelliğine sahipken kendileri zamanın dışında kalarak, zamanın yıkıcılığından muaf olurlar. İkinci örnek ise bunun tam tersi olan süreksiz ve kararsız mekânlardır. Festivaller, sergiler, panayırlar içinde bulunulan mekân ile oluşturulan yeni mekân arasında heterotopya görevi görür.

Beşinci ilke; bu mekânlar kamusal alanlar gibi serbestçe girilip çıkılabilen alanlar değildir. İçeri girebilmek için izin almak ya da kimi gereklilikleri yerine getirmek gerekmektedir. Kimi 
zaman ise aksine serbestçe girilebilmektedir. Bu durumda da mekânın tümüne ulaşım hakkı olmamaktadır. Belirlenmiş mahallere giriş hakkına sahip olunmaktadır. Ya kışla ve hapishane gibi mecburi olarak o mekânda olunmalıdır; ya da hamam ve sauna gibi girmek için kuralları, izinleri ve ritüelleri yerine getirmek gerekmektedir. Bu kategoride, içerirken dışlayan mimari yapıları ima eden bir çerçeve daha çizilmektedir (Şentürk, 2015, s.n.y).

Altıncı ilke; iki ayrı özelliği olan bir işleve sahip olmasıdır. Birinci özelliği, insan hayatının şekillendiği mahallerin hayali olduğunu düşündürmektir. İkinci özelliği ise, çarpık, düzensiz ve hatalı mekânlarımıza alternatif olarak 'mükemmel ve titiz' mekânlar üretmektir (Foucault, 1984, s.14).

Çalışmanın ikinci aşamasında seçilen araştıma nesnesi, Foucault tarafından tanımlanan altı ilke ışığında incelenecektir. Örnek mekân, ötekilik mekânları yaratması, heterojen ve özgün yapısı sebebiyle tercih edilmiştir.

\section{TOPHANE-İ AMIRE KÜLTÜR VE SANAT MERKEZI}

Tophane-i Amire, İstanbul'un fethinden önce Bizans döneminde "Metopan" olarak adlandırılan Tophane semtinde bulunmaktadır. Daha yeni araştırmalar Bizans döneminde bu semte Argypolis (Gümüş Kent) isminin kullanıldığını ortaya atmıştır. Nusretiye Camii karşısına denk gelen alanda bir Bizans kilisesinin olduğuna dair kanıtlar vardır (Tunç, 2014, s. 3). Fatih Sultan Mehmet tarafından şehrin alınmasından sonra semtte yapılan ilk yapı, top döküm evi olmuştur. Bunun nedeni; ateşli silahların icat edildiği tarihten itibaren büyük devletlerin güçlenmelerini sağlarken küçük devletlerin yok olmasına sebep olmasıdır. Büyük devletler dönemin şartlarından kaynaklı ateşli silahlar ve modern savaş aletlerine büyük önem vermiş, savaşlarda pek çok başarıyı bu yolla elde etmiş ve varlıklarını sürdürmeye devam etmişlerdir. 14. yy.'ın sonlarından itibaren ateşli silahları bulan ve kullanan Osmanlılar, topları kullanmanın yanında, top döküm teknolojisinde de hızlı bir gelişme göstermişlerdir (İpşirli, 2004, s. 722).

Fethedilen pek çok yer gibi İstanbul da, başta toplar olmak üzere çeşitli ateşli silahların kullanımıyla fethedilmiştir. Osmanlı'nın sabit top dökümhanelerine verdiği önem sebebiyle fetihten sonra semte top dökümhanesi yaptırılmıştır. Ancak Tophane-i Amire yapısının bulunduğu semtin isminin de Tophane olması nedeniyle karışıklığa sebep olması ihtimali doğmuştur. Karışıklığın ortadan kalkması için, Osmanlı Devleti kuruluşlarını ifade eden 'Amire' kelimesi, Tophane ismine eklenerek yapı tariflenmiştir (Tunç, 2014, s. 8).

Tophane-i Amire'nin kuruluş olarak Fatih Sultan Mehmet tarafından yapıldığı konusunda fikir birliği vardır. Ancak yapının Bizans döneminden kalma olup olmadığına dair fikir ayrılıkları söz konusudur. Bazı araştırmacılar yapının Fatih Sultan Mehmet tarafından yapıldığını iddia ederken, bazı araştırmacılar Bizanslılardan kaldığını, Fatih döneminde yenilendiğini iddia etmektedir. II. Beyazıd döneminde topçuların ve dökücülerin kalabileceği yeni odalar oluşturmak amacıyla, yapıya eklentiler yapılmıştır. (Fot. 1) Top dökümhanesinin yoğun işlevi sebebiyle yalnızca yapıya eklentiler yapılmakla kalmamış, semtin gelişimi de bu yönde etkilenmiştir. Yapıyla doğrudan veya dolaylı ilişkide olan ambarlar, mahzenler, tezgâhlar, top döküm fırınları ile semtin askeri bir alan olarak geliştirildiği görülmektedir. Ayrıca topçu başı, topçu, dökümcü ve gerekli personelin büyük bir bölümünün kışlaları da bu semtte yer almıştır. Osmanlı için, üretilen bu silahların büyük bir siyasi güç olması sebebiyle Tophane-i Amire'ye ve yapının bulunduğu semte de önem 
verilmiştir. Osmanlı devleti burada üretilen ateşli silahlar ile daha sonra siyasi rakipleri olacak Memlüklere, Afrika ve Güney Asya'daki bazı İslam devletleriyle, Orta Asya'daki zor durumda bulunan muhtelif Türk devletlerine top, tüfek, barut ve topçu gibi malzeme ve iş gücü yardımı yapmıştır (İpşirli, 2004, s. 724).

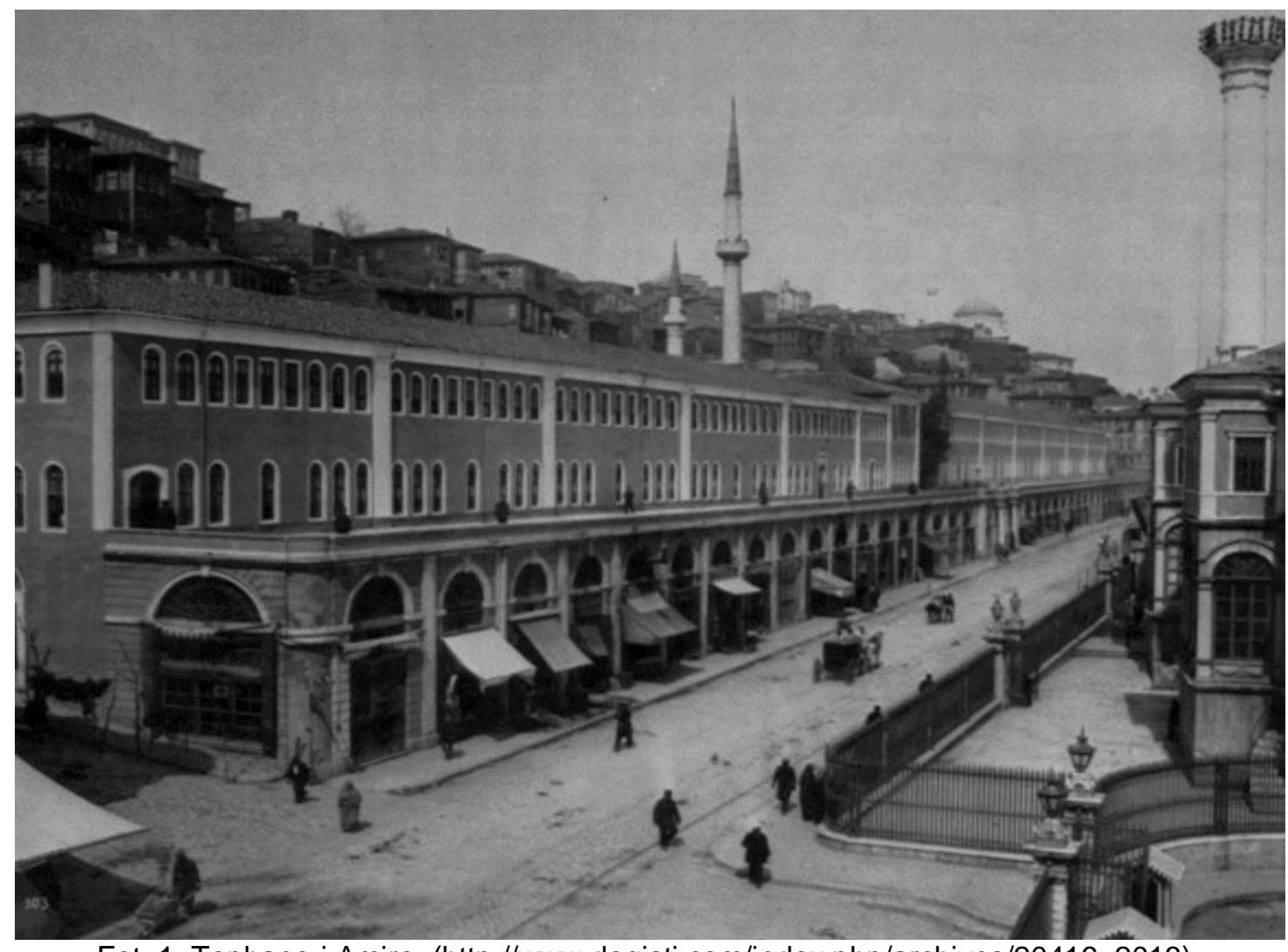

Fot. 1: Tophane-i Amire, (http://www.degisti.com/index.php/archives/20416, 2013). 


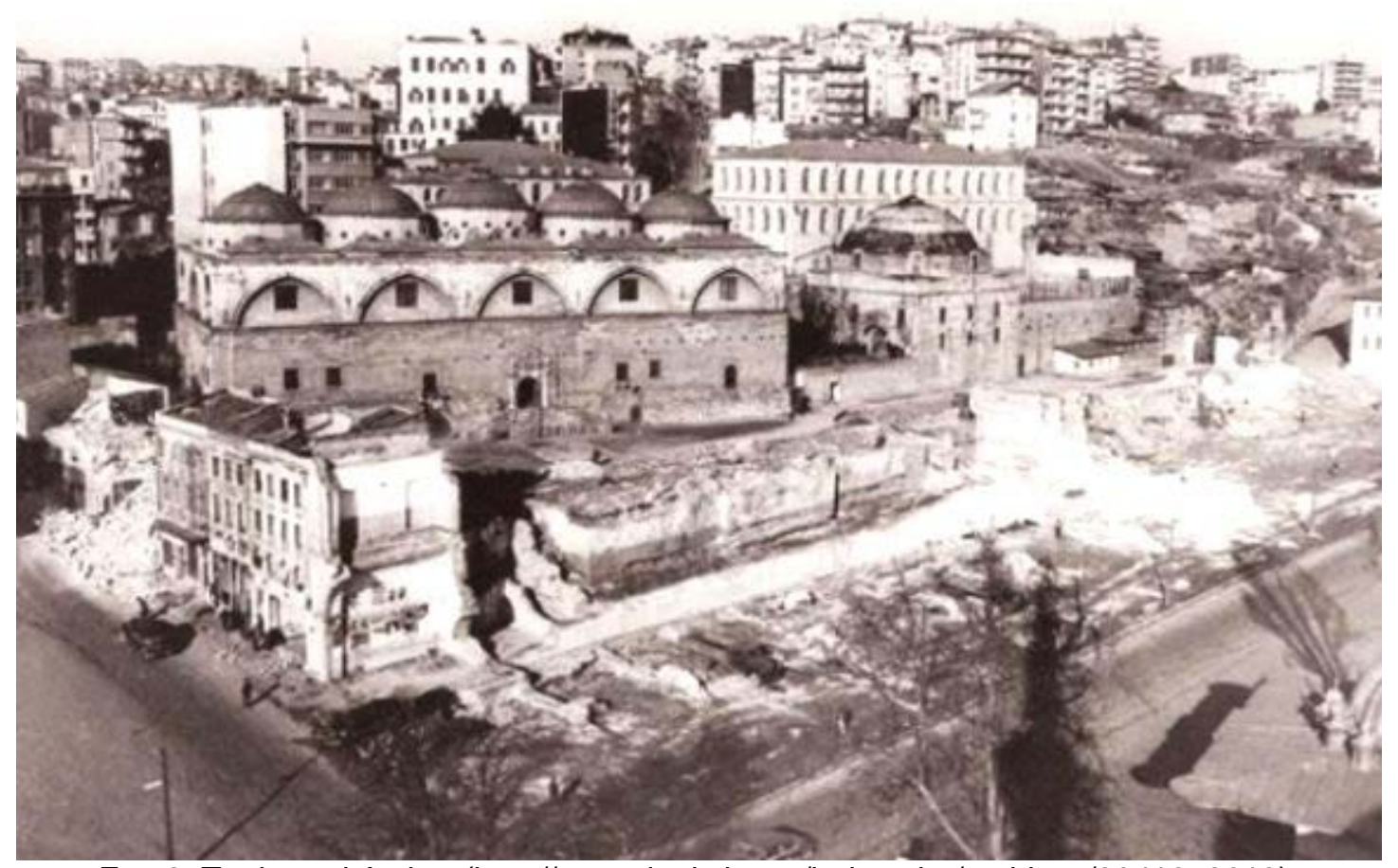

Fot. 2: Tophane-i Amire, (http://www.degisti.com/index.php/archives/20416, 2013).

Kanuni Sultan Süleyman döneminde yapı tamamen yıkılarak yerine büyük bir Tophane binası yaptırılmıştır. Yapılan yeni bina pek çok işlevi barındırmaktadır. Ancak esas işlevi sebebiyle yüksek ateş kullanılan yapı, yangın ve deprem gibi sebelerle defalarca hasar görmüştür. Bina, 1719 yılında semtte çıkan büyük bir yangında büyük ölçüde zarar görmüştür. (Fot. 2) 1723 yılında III. Ahmed'in emriyle yeniden yaptırılmış, bu sırada küçük topların dökümü için tek kubbeli yeni bir bina daha eklenmiştir. Tophane-i Amire Kârhanesi 1743 senesinde tamamen yıkılmış ve mimar Mustafa Ağa'nın planlaması ile tekrar yapılmıştır (Tunç, 2014, s. 15). Dönemin modern teknikleri ile inşa edilen yapının üzerinde padişahın, sadrazamın ve mimarın isimleri hâvi kitabesiyle hâlâ mevcuttur.

Şafak Tunç'un çalışması ışığında edinilen bilgilere göre; "Binanın mimarlığını yapan Mustafa Ağa, aynı zamanda topçu başı olduğunu, çeşitli yerlere yerleştirdiği top figür ve süslemeleriyle göstermiştir. Meselâ, binanın kemerlerinin dıştan bütün bağlantı taşları top namlusu şeklinde yapılmıştır. Deniz tarafındaki duvarın üst köşelerinde, tekerlekli kâideleri ile birlikte işlenmiş, ağızdan dolma şâhî top kabartmaları da halen görülebilmektedir. Mustafa Ağa ayrıca, güneye bakan ana kapı üzerine mermer bir kitabe yerleştirmiştir. Kitabenin sağında, Mustafa Ağa'nın kendi elinden çıkma I. Mahmud'un bir tuğrası bulunmaktadır. Tuğranın solunda, Fahreddin Yahya adlı bir kâtibin taşa hâkkettiği, şair Şem'i'ye ait bir tarih manzumesi bulunmaktadır" (Tunç, 2014, s. 16).

1743 yılında yapılan bu yenilemeden sonra yapı, daha çok kez yangın geçirmiş ve çeşitli hasarlar görmüştür. Bu nedenle çeşitli eklemeler ve eksilmeler olmuştur. Cumhuriyetin ilanına kadar kullanılmaya devam edilen yapı, Birinci Dünya Savaşı'ndan sonra önemini 
kaybetmiştir. Uzun süre atıl olarak kalan yapılar 1992 senesinde Mimar Sinan Güzel Sanatlar Üniversitesi'ne devredilmiştir. Tophane-i Amire Kültür ve Sanat Merkezi ismiyle sergi salonu olarak kullanıma açılmıştır. (Fot. 3)

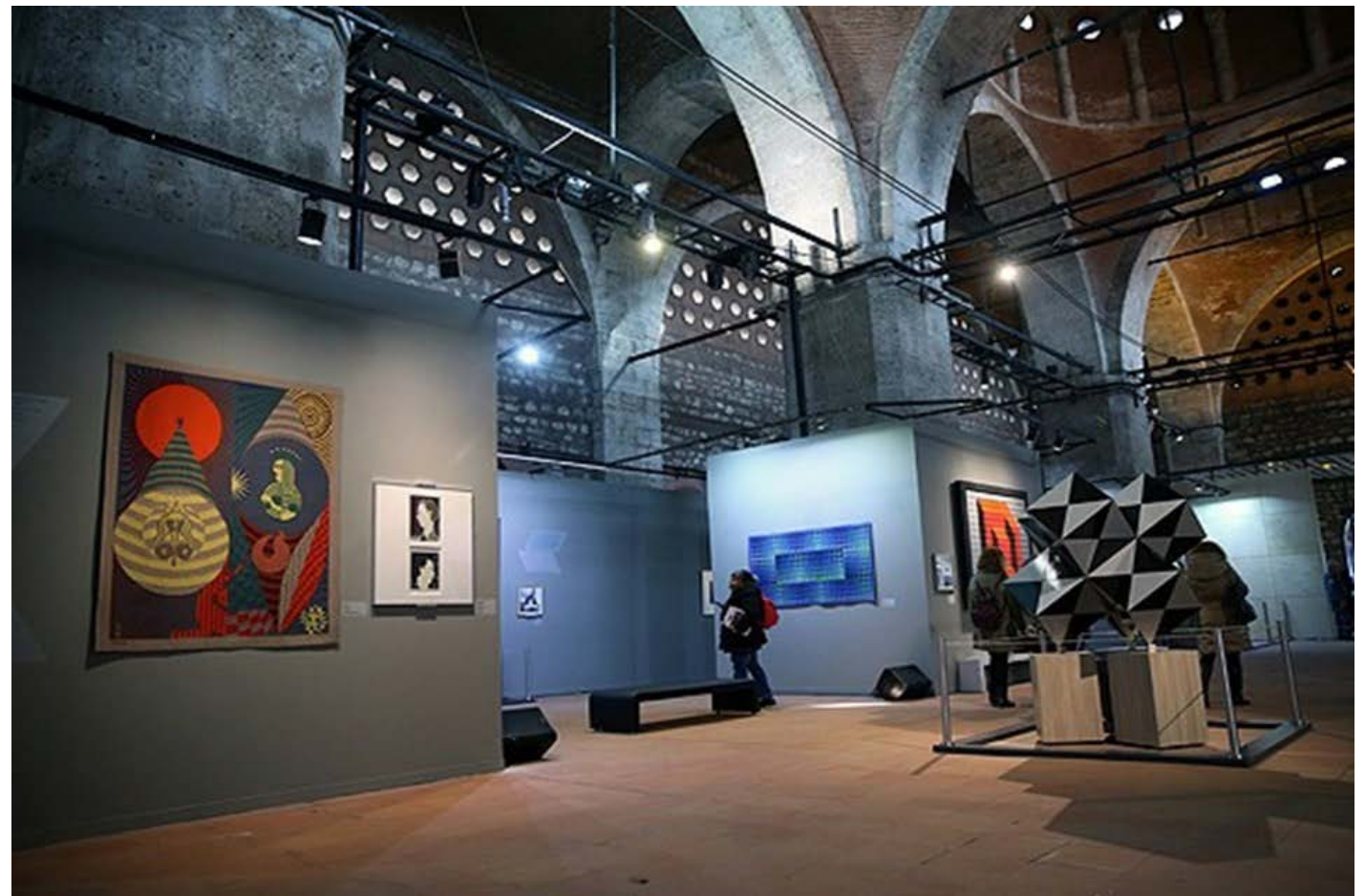

Fot. 3 : Tophane-i Amire, (https://www.ntv.com.tr/sanat/victor-vasarely-retrospektifi-sergisisanatseverlerle-bulustu,-kjWAWDceU6Eeo1msUFjHw, 2017).

Bu tarihi-askeri binada, Tophane-i Amire Beş Kubbe, Tophane-i Amire Tek Kubbe ve Tophane-i Amire Sarnıçlar olmak üzere üç ayrı sergi holü bulunmaktadır. Sergi hollerinde Türkiye'den veya farklı ülkelerden gelen sanatçıların eserleri sergilenmektedir. Yapının bulunduğu çevre, tarihi, değişen işlevi ve geçirdiği tarihsel sürecin izlerini taşıması nedeniyle heterotopik bir mekân olarak yorumlanabileceği düşünülmüştür. Bunun yanında, sergi salonu olarak kullanılıyor olması da örneklem olarak tercih edilme sebebi olmuştur.

\section{TOPHANE-I AMIRE KÜLTÜR VE SANAT MERKEZI'NIN HETEROTOPIK DEĞERLENDIRMESi}

Foucault heterotopya kavramını tanımladığı altı ilke içinden dördüncü ilkeyi zaman kavramı üzerinden değerlendirmiştir; "Heterotopyalar çoğu zaman, zaman dilimleriyle bağlantılıdır. İnsanlık geleneksel zamandan bir tür kopuş noktasına vardığında tam kapasite çalışır heterotopya" (Foucault, 1984, s. 12). Dördüncü ilkeyi iki ana eksende yapılandırmıştır. İlki zamanı depolayan mekânlardır. Müzeler ve kütüphaneleri bu bağlamda değerlendirmiştir. Bahsedilen mekânlar tüm zamanları ve çağları bir yerde toplarken kendisi zamanın tahribatından muaf kalır. Bu haliyle Foucault'un tabiriyle 'geleneksel zamandan' kopuş noktası yaşatan bir mekân özelliği kazanır. Bachelard da bu kopuş noktasının mekân ile bağını tanımlarken; "Gerçekten de düşleme, ilk andan itibaren bütünüyle oluşmuş bir durumdur. Başlarken hiç görülmese de, aslında hep aynı biçimde başlar. Yakındaki nesneden kaçar, derhal uzaklaşır, başka bir yerdedir, başka bir yerin 
mekânındadır"' demiştir (Bachelard, 2014, s. 223). Zaman kavramı üzerinden kurgulanan dördüncü ilkeye karşılık gelebilecek diğer mekânlar ise müze ve kütüphanelerin tam zıttı özelliktedir. Bu mekânlar uçucu ve süreksiz mekânlardır. Festivaller, panayır yerleri ve geçici sergiler mekânda süreklilik göstermezler. Fonksiyonları gereği mekânda ziyaretçilerdir. Mutlak olarak şimdiki zamana aittirler. Geçici olarak bulundukları mekânların, önceki ve sonraki etkilerini bertaraf ederek kendi düzenlerini oluştururlar. Böylece kalıcı mekânın etkisi ve işlevi ne olursa olsun kullanıcı geçici mekânın etkisine kapilır.

Tophane-i Amire binası mevcut fonksiyonuyla değerlendirildiğinde özellikle dördüncü ilkeye karşılık gelmektedir. Mimar Sinan Güzel Sanatlar Üniversitesi'ne devredildiğinden beri kültür ve sanat merkezi olarak işlevlendirilmiştir. Pek çok geçici sergiye ev sahipliği yaparak Foucault'un işaret ettiği gibi; ziyaretçilerin içinde bulunulan mekândan, sergilerin etkisi ile değişkenlik gösteren 'öteki' mekânlara geçişini sağlamaktadır. (Fot. 4-5) Üç ayrı sergi salonunda farklı sanatçıların eserlerine ev sahipliği yaparak, her salonunda serginin konusu doğrultusunda ziyaretçilerini algısal olarak başka mekânlara götürür ve ayna görevi görür.
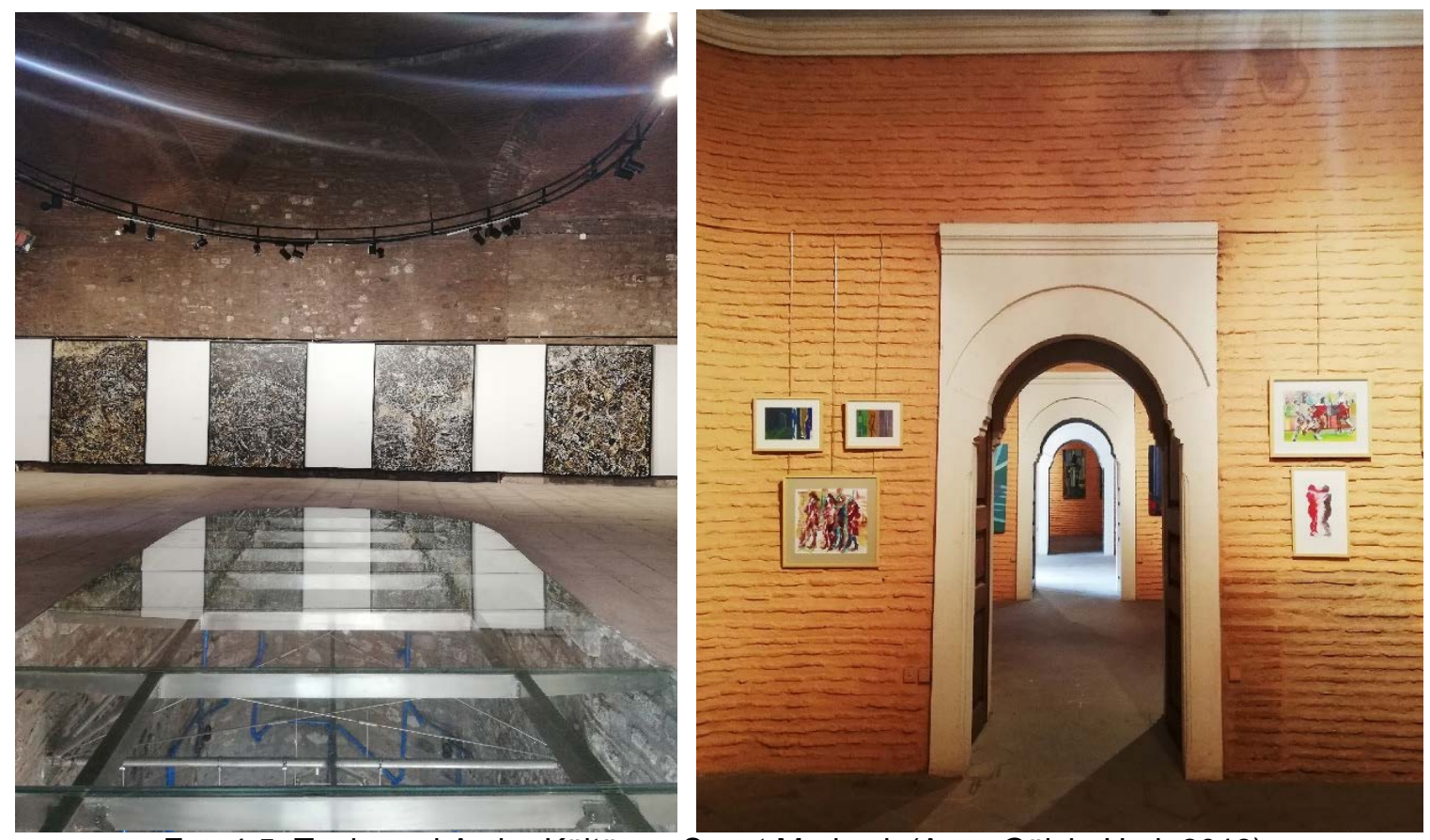

Fot. 4-5: Tophane-i Amire Kültür ve Sanat Merkezi, (Ayşe Gülçin Ural, 2018).

Ele alınan örneğin seçilmesinin diğer sebebi, yapının altı ilkeden birini karşılamasının yanında diğer ilkelere ait özellikler de taşımasıdır. Foucault ikinci ilkede; "Toplumun mevcut bir heterotopyayı tarihi boyunca bambaşka biçimlerde işletebileceğidir. İçinde vuku bulduğu toplumun senkronisi uyarınca başka başka işlevler görebilir" demektedir (Foucault, 1984, s. 11). Bu ilkeyi toplumsal süreç üzerinden değerlendirmek gerekir. Cumhuriyet döneminden önce, savaş konusu toplum ve idari kararlar üzerinde belirleyici bir etkiye sahip olmuştur. Savaşta kullanılan teçhizatların başında gelen topların üretimi için mekânlar oluşturulması önemli bir gereklilik haline gelmiştir. Burada çalışan insanların barınması ve intiyaçlarının karşılanması da yapının fonksiyonunun devamında ortaya 
çıkan bir gereklilik olmuştur. Ancak zaman içinde, hem dünya düzeninde hem coğrafyamızda gerçekleşen özellikle yönetimsel ve teknolojik değişimler, savaşları gündelik pratiklerimizde odak olmaktan çıkarmıştır. Şehir merkezlerinde veya merkeze yakın konumdaki mevkiilerde savaşın etkilerinin silikleşmesi amaçlanmıştır. Modern bir topluma doğru atılan adımlar bu tip yapıların işlevini değiştirmeyi, kültür ve sanat alanında ilerlemeyi gerektirmiştir. Tophane-i Amire binası bunun önemli bir örneğidir.

Üçüncü ilke; Foucault tarafından "Tek bir gerçek yer üzerinde aslında bir araya gelmesi imkansız birkaç mekânı, birkaç mahali üstüste bindirebilir" olarak tanımlanmıştır (Foucault, 1984, s. 12). Foucault bu ilkeye örnek olarak sinema ve tiyatroları göstermiştir. Tophane-i Amire binası kültür ve sanat merkezi işlevinden dolayı zaman zaman sergiler doğrultusunda gösterimlere ev sahipliği yapmaktadır. Örneğin 2011 senesinde sürrealist sanatçı Salvador Dali'nin 'İlahi Komedya', 'Sürrealizm İzleri' ve 'Gala İle Akşam Yemeği' sergi dizisi sırasında Dali'nin hayatını ve röportajlarını gösteren video sunumu yapılmıştır. Osmanlı mimarisi ile yapılmış olan bu top üretim binasına girişte, hala bulunan topların yanından geçilerek sergi salonlarında İspanyol sanatçı Salvador Dali'nin sürrealist dünyasına adım atmak mümkün olmuştur. (Fot. 6) Yapının bu yönüyle bir araya gelmesi imkânsız mekânlar, aynı anda içiçe bulunması zor olan kültürler bir araya getirilmiş, mevcut mekânda 'öteki mekân' oluşturulmuştur.

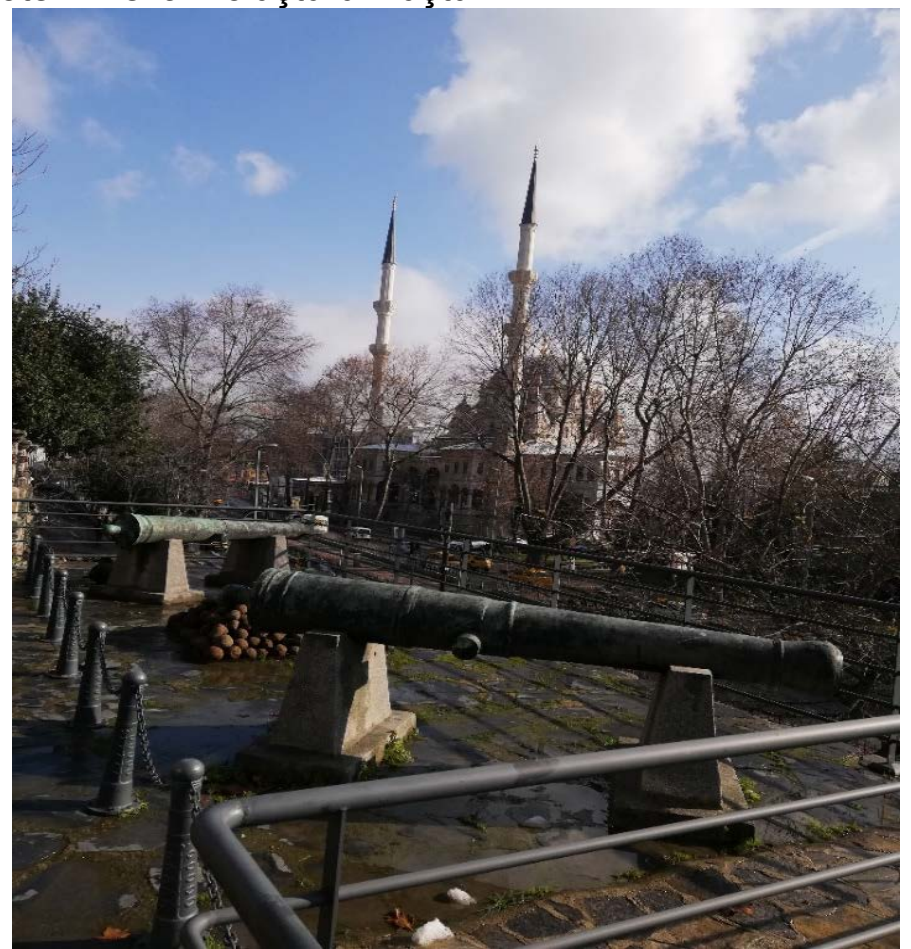

Fot. 6: Tophane-i Amire Kültür ve Sanat Merkezi, (Ayşe Gülçin Ural, 2018).

Altıncı ilke ise; "Geriye kalan mekânın tümüne dair bir işlevi olmasıdır" (Foucault, 1984, s. 14). Bu ilke küçük ya da büyük ölçekte değerlendirilebilir. Heterotopya, yapının belli bir mahalinde yaratılan yanılsama mekânının, yapının diğer mahalleri ile olan ilişkisi üzerinden okunabilir. Aynı zamanda, yapının kendi dışında kalan diğer mekânlarla olan ilişkisi ve hatta coğrafi mekân üzerinden de okunabilir. Burada önemli olan Foucault'a göre; "Bir yanılsama mekânı yaratarak, bütün gerçek mekânların, insan hayatının 
bölümlendiği bütün mahallerin daha da hayali olduğunu teşhir etmek, yahut da öteki olan bir mekân, bizimki ne kadar düzensiz, çarpık ve savruksa o kadar mükemmel ve titiz başka bir gerçek mekân yaratmaktı"' (Foucault, 1984, s. 14). İlkenin ilk bölümü yanılsama mekânları, ikinci bölümü giderme mekânları olarak tanımlamıştır. Tophane-i Amire binasının çevresi ile ilişkisi göz önüne alınarak, yapı giderme mekânı olarak değerlendirilmektedir. Yapının bulunduğu semt, savaşlar ve değişen yönetimlerin etkisi ile gerek kullanım gerek yapılaşma olarak değişikliklere uğramıştır. Osmanlı döneminde top döküm merkezleri ve askeri kışlaların bulunduğu bir sanayi bölgesi olarak kullanılmasının yanında, farklı etnik grupların yerleştikleri bir alan olma özelliğine sahip olmuştur. Aynı zamanda liman olarak da kullanılmıştır. Türkiye Cumhuriyeti'nin kuruluşunu takiben etnik grupların çoğu Tophane'den ayrılmış, yerine Türkiye'nin farklı bölgelerinde yaşayan kişiler gelip yerleşmiştir. Aynı zamanda semtte bulunan top döküm faaliyetleri sonlandırılmıştır. Tüm bu nedenlerle Tophane semti hem geçmişte hem de bugün toplumsal değişimlerin etkisiyle çalkantılı bir yapıya sahip olmuştur. Cumhuriyet dönemi ile birlikte modernleşen yeni yönetim anlayışı etkisinde Tophane'nin askeri ağırlıklı kullanımı sonlandırılarak yeni kimliği ile yapılaşma ve düzenlemeler yapılmıştır. Semt, artan nufüsu, şehir merkezlerine yakınlığı, toplumsal değişimlerin etkisi ile karışık ve düzensiz bir yapıya sahip olmuştur. 'Eski'nin imajını silmek amacıyla yapılan değişimlerin en önemlilerinden biri adını semtten alan Tophane-i Amire binasının fonksiyonel değişimi olmuştur. Yenilenen Tophane-i Amire binasının yeni fonksiyonu ile semtin düzensiz ve çarpık yapısının tersine, semtin olması planlanan düzenli, modern ve titiz yüzünü yansıtan gerçek bir mekân yaratılmıştır. Foucault 'Mekân, Bilgi ve İktidar' söyleşisinde 'Kent artık bir ayrıcalık yeri, bir alanlar, ormanlar ve yollar bölgesindeki bir istisna olarak algılanmaz. Bunun yerine, ortaya koydukları sorunlar ve edindikleri kuvvetler itibariyle kentler bölgenin bütününe uygulanan yönetim aklı için model teşkil eder." demektedir (Foucault, 1982, s. 241). Bu nedenlerle Foucault'un altıncı ilkesinde bahsetmiş olduğu gibi, örneklem olarak seçilen yapının yeni bir modeli temsil ettiği ve giderme mekânı özelliğine sahip olduğu görülmektedir.

\section{DEĞERLENDIRME VE SONUÇ}

Foucault'un heterotopyaya dair tanımları esas alınarak yapılan bu araştırmada, heterotopya kavramı detaylı bir şekilde incelenmiştir. Kavramın mekânlar üzerindeki yansıması irdelenmiştir. Mahallerin, kullanıcısını mevcut durumda bulunduğu mekândan ayırarak, yanılsama mekânına geçişini sağlayabilmesi durumunda 'heteropik mekân' olarak tanımlanacağı sonucuna varıımıştır. Yanılsama mekânının ya da Foucault'un ifadesi ile 'Öteki Mekân'ın oluşması ve ayna etkisi yaratması durumunda kullanıcının 'öteki ben' ile karşılaşmasının beklendiği tespit edilmiştir. Heterotopik olarak tanımlanabilecek mekânların detaylandırıldığı ve örneklendirildiği altı ilke aktarılmıştır. Bu ilkelerle Foucault'un 'öteki mekân' tanımı ve 'heterotopya-heterotopik mekân' kavramları irdelenmiştir.

Tophane-i Amire Kültür ve Sanat Merkezi'nin tarihi yapısı, mimari özellikleri ve eski işlevine dair izleri hala korumasının yanında yeni işlevi ve eski işlevi arasındaki zıtlık bu yapının örneklem olarak seçilmesine sebep olmuştur. Araştırma nesnesi olarak seçilen yapının, altı ilkeden dördünde karşılık gelebilecek özellikte olduğu tespit edilmiştir. Michel Foucault'un heterotopya kavramını tanımlamış ve detaylandırmış olduğu ilkelerin her biri farklı heterotopik mekânların özellikleridir. Bunun yanında heterotopik mekânın bu ilkelerden bir kaçına uygunluk göstermesi de olanaklıdır. Bu nedenle Tophane-i Amire Kültür ve Sanat Merkezi öncelikle bütün ilkeler üzerinden değerlendirilmiştir. Ancak 
dördüncü ilkede yapılmış olan tanım ile tam olarak örtüştüğü, ikinci, üçüncü ve altıncı ilkenin özelliklerini de taşıdığı görülmüştür. Yapılan literatür taraması ve bulgular sonucunda Tophane-i Amire Kültür ve Sanat Merkezi'nin heterotopik mekân olarak tanımlanabileceği sonucuna varılmıştır.

\section{KAYNAKLAR}

Bachelard, Gaston, Mekânın Poetikası, 2. B., Çev.: Alp Tümertekin, İthaki Yayınları, İstanbul 2014.

Dede, Gülin, Heterotopik Bir Mekân Olarak Tiyatro Sahnesi: Uyumsuz Tiyatro, Yüksek Lisans Tezi, İstanbul Teknik Üniversitesi, Fen Bilimleri Enstitüsü, İstanbul 2010.

Elden, Stuart, Bölge Tarihini Nasıl Yapmalıyız?, Cogito, Yapı Kredi Yayınları, İstanbul 2012, ss. aralığı: 480-504.

Foucault, Michel, Of Other Spaces: Utopias and Heterotopias, Architecture /Mouvement/ Continuité, 1984.

Foucault, Michel, Space, Power, and Knowledge, 1. B., The Foucault Reader, Pantheon Books, New York 1984.

Girgin, Mustafa, Ertürk, Mustafa, Aysel, İlker, Akça, Bayram, Other Spaces of Muğla, 3rd International Geography Symposium - GEOMED, Ed: Recep Efe, İbrahim Atalay, İsa Cürebal, 2013, ss. aralığı: 393-398.

İpşirli, Mehmet, Tophane-i Amire ve Top Döküm Teknolojisi (XV.-XVI. Asırlarda), Türkiye Araştırmaları Literatür Dergisi, 2004, ss. aralığı: 721-725.

Kaymaz Koca, Senem, Jonathan, Hale, 'Üçüncü/Öteki Yer' Üzerine Bir Kavramsallaştırma Denemesi: Mekansal Bir Trilojinin İçinde Saklı Hikayelerin Keşfedilmesi, Megaron, 2017, ss. aralığı: 488-496.

Nakıboğlu, Gülsün, Ütopyadan Doğmak, Ütopya Doğurmak: Heterotopya Kavramı ve Heterotopya Bağlamında Balık İzlerinin Sesi, FSM İlmî Araştırmalar İnsan ve Toplum Bilimleri Dergisi, 2015, ss. aralığı: 381-407.

Nalbantoğlu, Hasan Ünal, Nedir Mekân Dedikleri? Zaman-Mekân içinde, 1. B., Yem Yayınları, İstanbul 2008, ss. aralığı: 88-105.

Şentürk, Levent, 'Heterotopoloji'ye Giriş: Heterotopyalar Için Bir Nomenklatura Denemesi, https://xxi.com.tr/i/heterotopolojiye-giris-heterotopyalar-icin-bir-nomenklatura-denemesi-i, Erişim tarihi ve saati: 10.12.2018,14:00.

Tunç, Şafak, Tophane- i Amire ve Osmanlı Devletinde Top Döküm Faaliyetleri, 1. B., Kişisel Yayınlar, 2014.

Tophane-i Kürire ve Sanat Merkezi Tarihçe, http://www.msgsu.edu.tr/pages/ModalWindowContent.aspx?cid=1429\&rcid=1429, Erişim tarihi ve saati: 04 Şubat 2019,16:00. 